\title{
Determinants of Earnings Response Coefficient (ERC) and its Impact on Trading Volume
}

\author{
HERNI KURNIAWATI \\ Faculty of Economics and Business, Trisakti University \\ Email: herni_potter@yahoo.com \\ SUSI DWIMULYANI \\ Faculty of Economics and Business, Trisakti University \\ Email: susi.dwimulyani@yahoo.com
}

\begin{abstract}
The study aims to prove whether the factors that influence the quality of corporate profits, as measured by earnings response coefficient, also can affect the level of trading volume in the stock market. This study differs from previous research in which only examine the factors which consist of the company's growth, systemic risk, and the persistence of earnings to the earnings response coefficient. While this study wanted to know and prove that the factors which consist of the company's growth, systemic risk, and the persistence of earnings can also affect the level of trading volume, both descend and ascend. By looking at the information on the level of trading volume, the prospective investor / investors can ensure that stock companies listed on the stock exchange market is not sleeping, because for novice investors invest in stocks beds provide a sense of worry if the money they get caught in the bed stock so it can not withdraw funds if needed quickly. Research using panel data regression analysis with a sample period of 2012-2016 unlisted manufacturing companies in Indonesia Stock Exchange. Results of the study (1) The company's growth negatively affect earnings response coefficient; (2) Systematic risk has a positive effect on the earnings response coefficient (3) The persistence of earnings positive effect on earnings response coefficient; (4) Earnings response coefficient negatively affect the volume of stock trading; (5) The company's growth directly affects the volume of stock trading; (6) Systematic risk no direct impact on the volume of stock trading; (7) The persistence of income directly affects the volume of stock trading. It can be concluded that the earnings response coefficient can be a mediating variable connecting factors that affect earnings response coefficient of the level of trading volume.
\end{abstract}

Keywords: The Company's Growth, Systematic Risk, Earnings Persistence, Earnings Response Coefficient, Share Trafficking Volume Level.

\section{Introduction}

The period of 2012-2017, Indonesia entered into the list of the top five emerging markets issued by Global Intelligence Alliance, where the first position is occupied by Brazil, followed by India, China, Russia, and the last is Indonesia (Sugiyarto, 2012). Being fifth in the list of emerging markets, Indonesia has shown increasing economic growth of the chemical industry, manufacturing, service, and finance, which beat the economic growth of developed countries such as Singapore, which is in the final 15 emerging markets (Sugiyarto, 2012). The impact of Indonesia entered into the list of emerging markets prove that investing in developing countries have a greater probability of developing for investors. As Indonesia entered into the list of emerging markets, has attracted many investors to invest, and one way of investors to make a 
decision whether to invest or not is by looking at the information on income in the income statement, part of the financial statements. The profit for the investor information should be appropriate to tell the condition of the company's performance, which the company making a profit can be said the company has a maximum reach company goal for earnings reflects the company's financial performance was good. Such earnings information is said to have the ability to respond to the market so that it is concluded that the information is of high quality, and in this study, good earnings quality is measured by the earnings response coefficient (ERC). ERC is an accurate measurement of the quality of earnings duo describe the association between the rates of return on investment information from the company as the market reaction (Rosdini, 2010). ERC that high value means lower profits prove to provide information to investors in making decisions related to investments, while the value of low ERC is the opposite (Ambarwati, 2008). The intensity of the ERC can be influenced by many factors that have been tested with the results are inconsistent. Factor growth companies that affect the ERC gives inconsistent study results are the significant positive effect on the ERC (Collins \& Kothari, 1999), the significant negative effect on the ERC (Dira \& Astika, 2014; Jang, 2007) and does not affect the ERC (Subagyo \& Olivia, 2012).

Systematic risk factors also provide research results are also inconsistent that significant positive effect on the ERC (Collins \& Kothari, 1999; Lipe, 1990) and has no effect on the ERC (Margaretta, 2006). The last factor that gives inconsistent research results is the persistence of earnings where earnings persistence significant positive effect on the ERC (Kormendi \& Lipe, 1989; Scott, 2015) and no positive effect on the ERC (Rofika, 2015). For these reasons the motivation to do retesting three factors that affect the ERC and associated impact on stock trading volume in the stock market.

The volume of stock trading can be considered as a parameter of an issuer's stock liquidity available information on the Indonesia Stock Exchange. Trading volume information commonly used by market participants to commit acts of buying and selling shares in order to obtain the abnormal returns, which is often equated with profit. Rise and fall of the issuer's shares trading volume can be influenced by the quality of earnings, as measured by the ERC, as earnings quality (indicated by the value of high ERC) responded quickly to the market which is good news for the market (Suryawijaya \& Setiawan, 1998). Besides other factors that affect the volume of stock trading is the company's growth, earnings persistence, systematic risk Stock Price Index (CSPI) and the exchange rate of the USD. The volume of stock trading as a tool to see the response of market participants to information published by the company activity indicators rise and fall of stock trading volume in the stock (Halim \& Hidayat, 2000). Therefore, companies that could potentially grow to serve as the good news and the market should react positively (ibid).

Earnings persistence means that the earnings capability as a parameter earnings in future periods (in earnings) generated the company repeatedly (repetitive) in the long term (sustainable) (Penman, 2001). Recurring profit generated is referred to as earnings quality (Penman, 2001), and earnings quality information is good news resulting in increased trading volume (buy shares) (Suryawijaya \& Setiawan, 1998).

Market participants when deciding to invest using the funds, the most important thing to do with him is the systematic risk of shares will be borne after buying shares of the issuer. The average market players only willing to bear certain risks at the level of a certain return anyway. Consequently, if the risk is considered too high, market participants act to stop investing in the stock. So that these issues affect the decline in trading volume issuers (Hadya, 2013).

CSPI increased value caused market participants will obtain a high capital gain while encouraging the interest of market participants to buy shares of a massive so that positive effect on increased demand for their shares (Otok, Guritno, \& Suban, 2006). Dollar exchange rate weakened against the Indonesian Rupiah will certainly encourage the interest of market participants to buy shares in large quantities, causing the increase in trading volume due to demand for stocks (Otok et al., 2006). 
The purpose of the study is to verify whether the factors that influence the quality of corporate profits, as measured by the ERC, it can also affect the level of trading volume in the stock market, and investors do not invest in the stock beginner sleep. The result is a novice investor cannot disburse its funds quickly when funds are large is.

\section{Materials and Methods}

\section{Earnings Response Coefficient (ERC)}

Earnings quality is the profit that has the ability to reflect the continuation of profit for the future, which is determined along with the accrual component of the cash flow (Wijayanti, 2006). Dechow, Ge and Schrand (2010) in his research said that a higher profit provides more information about the company's financial performance features that are relevant to specific decisions made by decision makers. In addition, Dechow et al. (2010) in research categorizes the quality of earnings into three categories: Profit nature, including the persistence of earnings (earnings persistence), the magnitude of accruals (magnitude of accruals), the residual value accrual models (residual accrual models), the smoothing of income (earnings smoothness), and the loss of recognition accuracy (timely loss recognition).

1) The response of investors to profit, including earnings response coefficients (ERC).

2) External indicators of misstated earnings, including Accounting and Auditing Enforcement Releases (AAERs), the return statement (restatements), and the inefficiency of internal control procedures by the Sarbanes Oxley Act (internal control procedure deficiencies reported under the Sarbanes Oxley Act).

Of the three categories of income that has been described by Dechow et al. (2010) research institute, and is interested in using the ERC to measure the quality of earnings, citing the quality of earnings as measured better reflect the relationship and the return on investment information from the company as the market reaction (Rosdini, 2010). ERC research value calculated by the cumulative abnormal returns regressed with unexpected earnings.

\section{Determinants ERC}

Scott (2015) proved that the intensity of the ERC is caused by several factors including growth opportunities, earnings persistence, beta, capital structure, and firm size. The factors that influence the ERC were tested again in this study because the results of previous studies were inconsistent, namely:

\section{1) growth opportunities}

The meaning of the growth opportunity is the potential of the company to develop the operations of the company for the future by using investor funds to increase the value of the company (Tandelilin, 2010: p.314). In addition to raising the corporate value, growth opportunities for the company also responded positively by investors because it provides high gain future for investors, so it concluded that companies that have high chances to grow the higher the chances of profit in the future, as indicated by the value of the ERC high (Scott, 2015). To measure the value of growth opportunities using formula (Dhaliwal, Li, Tsang, \& Yang, 2011):

$$
\text { MarketToBookValue }=\frac{\text { MarketValue }}{\text { BookValue }}
$$


2) the persistence of earnings

The persistence of earnings is the company's ability to retain earnings over time and not just because of a certain event, investors need to be considered in making investments based on historical data the company is one of them through the persistence of earnings. Earnings persistence describe quality corporate profits and also prove that the company remains a going concern (Susanto, 2012). The persistence of earnings is calculated by (Chandarin, 2003):

$$
\text { Eit }=\alpha+\beta-1+\varepsilon
$$

Eit $\quad=$ Profit firm $I$ in period $\mathrm{t}$

Wait-1 = I company profits in the previous period

$\beta \quad=$ Persistence of earnings

$\varepsilon \quad=$ error

\section{3) Systematic Risk $(\beta)$}

Systematic risk is the risk that has an impact on all companies and these risks cannot be eliminated through diversification of portfolio assets. The level of systematic risk of companies measured by beta, where beta reflects the sensitivity of return companies to market return (JCI). Values beta companies high impact the high level of risk of the portfolio assets of a company, thus lowering the level of market demand for the stock. The fall in the level of market demand for the shares indicated that the market response is low (ERC). Systematic risk is calculated with the market model (Sharpe, 1964) using the formula of capital assets of pricing the model (CAPM):
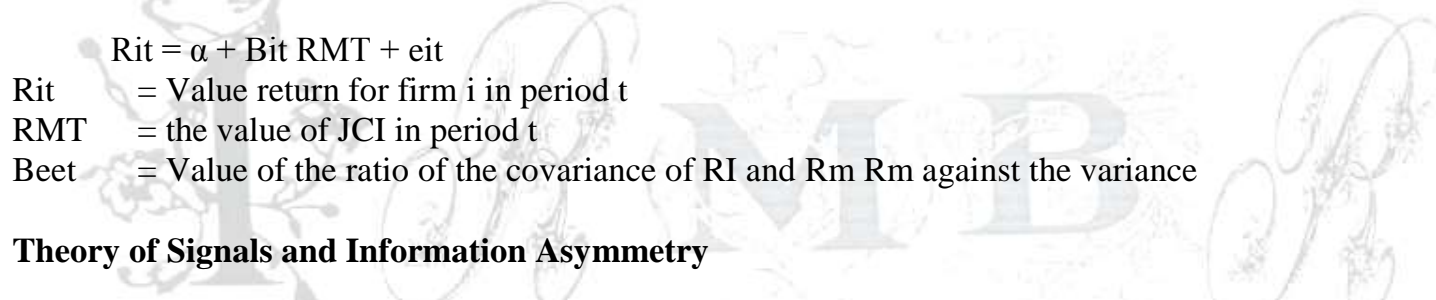

Brigham and Houston (2010) say that the theory of signal is the attitude of management in providing information to the market about how management sees an opportunity in the future. Asymmetry of information according to Jensen and Meckling (1976) is a condition in which no one party getting better than information with other parties. Asymmetry of information within the company occurs because the manager (agent) as the party who has more information than shareholders (principal), so affected the adverse selection problem because investors do not know exactly which companies performing well and which companies are under-performing. Signal theory in which the company should give a signal to the users of financial statements so as to avoid the occurrence of information asymmetry.

The signal is given by the company's management by the users of financial statements translated into good news or bad news. Examples of a good signal is an increase in sales over the previous year which led to an increase in profits from the previous year. Examples of a bad signal are the opposite, namely a decrease in sales compared to last year which led to a decrease in corporate profits. Well, the above signal indicates the company is in good condition going concern, whereas a bad signal indicating the company in bad condition.

Benefit from the signal theory is reducing information asymmetry by providing the financial information presented in the financial statements better quality. Qualified financial statements are to be audited by an external party (independent), namely public accounting firm to audit the result from their opinion on the financial information presented in the financial statements. The audit opinion that the financial statements of quality are unqualified. 


\section{Stock Trading Volume}

Total unit shares are traded on the exchange for a period of time which can be daily, weekly, or monthly (Bodie \& Kane, 2006). The volume of stock trading is usually used by market participants to see the market response to information circulating through the observation of changes in the volume of trade on the exchange. In addition, the volume of stock trading is also used to determine whether the type of individual investors assess the financial report can provide the information needed to make decisions that normal stock trading in the exchange (Husnan, 2005). If the number of shares traded on a stock transaction means the company increased demand by many investors and stock returns are also going up. Trading volume is calculated by dividing the total shares traded on the stock at time $t$ with the company's total shares outstanding at time $\mathrm{t}$ (Otok et al., 2006).

\section{Research Model and Hypothesis Development}

ERC is a form of response to market participants (investors) to information posted profits in the stock market. Opera- who responded by investors can be either good news or bad news. The shape of the good news that responded by the investor is the announcement of earnings information that an increase from the previous period or profits produced by the company is greater than expected. So that it impacts the positive sentiment that investors reacted to buy shares which increased the volume of stock trading. The market response (investor) is caused by many factors such as the persistence of earnings, the company's growth, the level of systematic risk, the quality of the auditor's report and others.

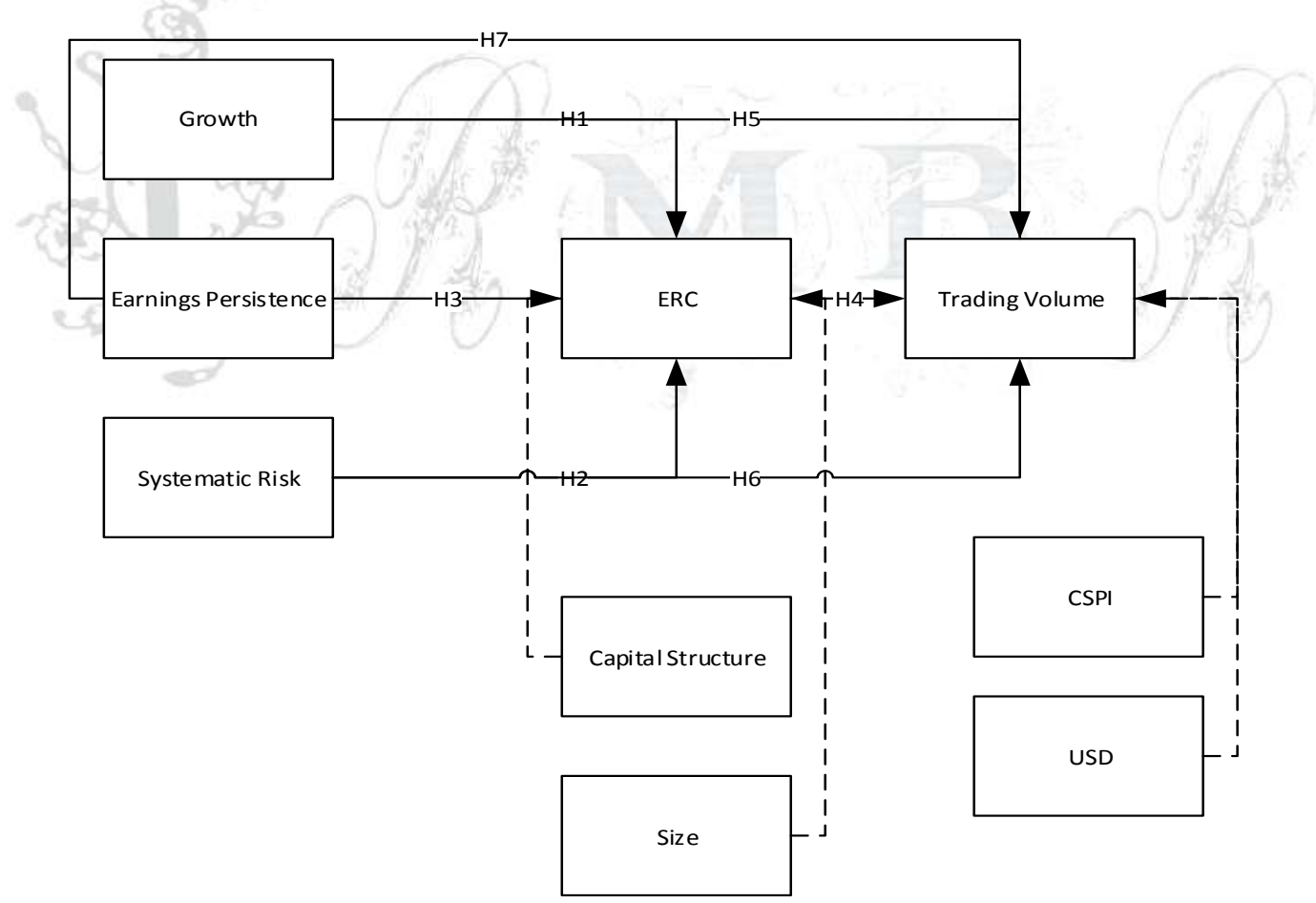

Figure 1: Conceptuel Framework

Susanto (2012) showed in his study that the systematic risk (beta) in investing for the auditor affect the value of the ERC, the smaller the value, the faster systematic risk markets respond to earnings announcements. (Harahap (2004) and Rofika (2015)) gave the results of different studies which found that systematic risk does not affect the ERC. Large-sized enterprise tends to produce a stable profit from year to 
year so it does not affect the ERC when the management company announced earnings (Barry, 2004; Harahap, 2004; Mulyani et al., 2007; Solehah, 2010; Susanto, 2012), as a small company showed different results, namely when the management company announced earnings tend to be responded by the market, this is evidenced by the share price fluctuating around the date of publication the results of the same research conducted by Scott and are already written off (2015), provide evidence that the company's earnings are persistent from year to year in the coming period will increase the value of the ERC.

The opportunity to grow a company is a guideline in classifying growth or failure of a company. Investors will be interested to invest in the company because of the certainty of return that would be acceptable in the future (Solechan, 2006). Thus, concluded that the company's growth opportunities in the future certainly increase its profit in the future (Mulyani et al., 2007; Susanto, 2012).

Solechan (2006) in his research stating the company that has the opportunity to grow can give no assurance that the returns will be accepted for the foreseeable future (return). These results are supported by some research that has been proved by Barry et al. (2007); Tiolemba and Ekawati (2008), and Susanto (2012). This study examined the relationship between the growths of the company with the ERC. So the hypothesis:

$\mathrm{H}_{1}$ : Growth of the company has a positive influence on the ERC

Easton and Zmijewski (1989) showed in his study that the systematic risk, known as beta stocks have a negative effect on the value of the ERC. This is because the investors still believe in profit as earnings power and return parameters obtained by investors in the future. These results support empirically and Kothati Collins (1987) and Rofika (2015). This study will examine the relationship between systematic risks to the ERC so that the two research hypotheses are:

\section{$\mathrm{H}_{2}$ : Systematic risk having a negative effect on the ERC}

Kormendi and Lipe (1987); Easton and Zmijweski (1989); Mulyani et al. (2007) proved in his research that the company that its profit persistent over time affecting positive against ERC. Profits persistence (unchanged) from year to year in the eyes of market participants is expected for certain market participants will be assigned the higher returns in the future. This study will examine the relationship between persistence profits by ERC, hypothesized in the hypothesis of three, namely:

$\mathrm{H}_{3}$ : Persistence of earnings has a positive influence on the ERC

Suryawijaya and Setiawan (1998) proved that stock trading volume has increased is due because of the large demand on the stock market. The increase in market demand for the shares is a response from investors on the information that has been published by a company that is a good information (good news). So this research will examine the relationship between the ERC with the stock trading volume hypothesis is formulated as follows:

\section{$\mathrm{H}_{4}$ : ERC has a positive influence on the volume of stock trading}

Parameters used by market participants to analyze the techniques to assess the stock price is trading volume (Halim \& Hidayat, 2000). Other uses of the volume of stock trading as a tool to see the response of market participants to information published by the company activity indicators rise and fall of stock trading volume in the stock (Halim \& Hidayat, 2000). Therefore, companies that could potentially grow to serve as a good news and the market should react positively (Halim \& Hidayat, 2000). So that his hypotheses are:

$\mathrm{H}_{5}$ : Growth companies directly influence the volume of stock trading 
Market participants, when investing funds, things noticed is the risk that will bear. They just want to bear certain risks at the level of a certain return anyway. Thus, if the risk is considered too high, the action taken investors are not investing in the stock. This will cause a decrease in the volume of stock trading companies (Hadya, 2013). So the research hypothesis is:

$\mathrm{H}_{6}$ : Systematic risk directly affects the volume of stock trading

Earnings persistence means that the earnings capability as a parameter earnings in future periods (in earnings) generated the company repeatedly (repetitive) in the long term (sustainable) (Penman, 2001). Recurring profit generated is referred to as earnings quality (Penman, 2001), and earnings quality information is good news resulting in increased trading volume (buy shares) (Suryawijaya \& Setiawan, 1998). So the hypothesis:

H7: The persistence of income directly affects the volume of stock trading

Using quantitative descriptive method with the type of causal investigation with the purpose of (1) demonstrate empirically the extent of influence the company's growth, systemic risk, and persistence return on earnings response coefficients. (2) Provides empirical evidence and analyze the extent to which the earnings response coefficient affects the volume of stock trading; (3) prove the direct influence of the company's growth, systemic risk, and persistence return on stock trading volume. The research variables consist of the company's growth, systemic risk, and the persistence of earnings as an independent variable and stock trading volume as the dependent variable. This study also used the intervening variables that earnings coefficient response. Measurement of growth companies with market-to-book ratio formula (Dhawil, 2011). Systematic risk is measured by the formula of capital assets pricing model (CAPM) simplified by Sharpe (1963). Regressed earnings persistence is measured by profit after tax of the company $i$ in period $t$ with profit after tax of the company $i$ in the previous period.

The variable stock trading volume as the dependent variable being measured formula dividing the number of shares $\mathrm{i}$ are traded on the stock with the number of shares outstanding i. Mediating variables, namely the ERC, which is calculated by regressed cumulative abnormal return (CAR) firm i in period $t$ with unexpected earnings (UE) firm $i$ in period t. The sample of research is manufacturing companies listed in Indonesia Stock Exchange with data retrieval using purposive sampling technique. The criteria are (1) Registered continuously at the Stock Exchange during the period from 2012 to 2016; (2) Publish financial statements / annual in Rupiah / USD consistently throughout the study period, 2012 to 2016; (3) Present financial report / annual audited years 2012 to 2016 with an unqualified opinion; (4) During the period 2012-2016 the company generates positive profits; and (5) The Company has a complete stock of data available in the site https://yahoofinance.com during the period 2012-2016, The results of the final study sample of 280 firm years regressed panel using E-views program.

\section{Research Model}

To prove the hypotheses that have been proposed, this research using panel data regression model with two models:

Panel regression model 1:

$$
\mathrm{ERC}=\mathrm{b} 0+\mathrm{b} 1 \mathrm{GR}+\mathrm{b} 2 \mathrm{PL}+\mathrm{b} 3 \beta i t+\mathrm{b} 4 \mathrm{SM}+\mathrm{b} 5 \mathrm{UP}+\mathrm{e}
$$

Where:

$\mathrm{ERC}=$ earnings response coefficients

$\mathrm{GR}=$ rate of growth of the company, for which data on ln right to do the regression for large data. PL $=$ the persistence of corporate profits 
$\beta=$ Systematic risk companies

$\mathrm{SM}=$ the capital structure of the company

$\mathrm{UP}=$ Size Companies

$\mathrm{e}=$ error

2-panel regression model:

$$
\text { VPS }=b 0+b 1 E R C+b 2 G R+b 3 P L+b 4+b 6 \text { USD b5IHSG } \beta i t++e
$$

Where:

VPS $=$ Volume of a stock trading company

IDX = composite stock price index issued by the Indonesia Stock Exchange

USD $=$ USD rate against the USD. Because data is large USD rate than when regressing ln USD at right.

$\mathrm{GR}=$ the growth rate of the company, for which data on ln right to perform because of the large data regression

\section{Findings and Results}

\section{Analysis Description}

Table 1 descriptive statistics for research Model 1 and 2

\begin{tabular}{|c|c|c|c|c|c|c|c|c|c|}
\hline 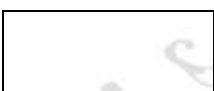 & ERC & VPS & growth & \begin{tabular}{|c|} 
earnings \\
Persistence
\end{tabular} & $\begin{array}{l}\text { Systemati } \\
\text { c Risk }\end{array}$ & \begin{tabular}{|c|} 
Capital \\
Structure
\end{tabular} & size & CSPI & USD \\
\hline mean & -0.00807 & 0.22143 & 4939406 & 0.994395 & $7.92 \mathrm{E}-29$ & 0.431260 & 2872299 & 0.085640 & 12306.00 \\
\hline median & 0.01616 & 0.08183 & 0.913006 & 0.998846 & $-3.78 \mathrm{E}-30$ & 0.424931 & 2836888 & 0.101898 & 12440.00 \\
\hline maximum & 0.15297 & $4,566.103$ & 2764635 & 1119205 & $3.79 \mathrm{E}-27$ & 0.999292 & 3371658 & 0.297237 & 13795.00 \\
\hline Minimum & -0.28044 & 0.00012 & $7,262,364$ & 0.775719 & $-3.35 \mathrm{E}-27$ & $-2,820,528$ & 2425884 & 0.117290 & $\begin{array}{c}9.67 \\
\text { million }\end{array}$ \\
\hline Std. Dev. & 0.14789 & 0.47537 & 8870288 & 0.119956 & $2.26 \mathrm{E}-27$ & 0.272825 & 1762034 & 0.109960 & 1449945 \\
\hline skewness & -0.948977 & 5361826 & 1399158 & -0.903992 & 0.186715 & $-5,848,353$ & 0.609954 & $\begin{array}{c}- \\
0.946661\end{array}$ & $\begin{array}{c}- \\
0.895211\end{array}$ \\
\hline sis & 2629469 & 3879775 & 3225706 & $\begin{array}{c}2.52721 \\
\text { million }\end{array}$ & 2509106 & 7331903 & 3019161 & 2683008 & 2498823 \\
\hline Jarque-Bera & 4362773 & 16292.21 & \begin{tabular}{|l|}
9195101 \\
\end{tabular} & 4074391 & 4438313 & 59285.09 & 1736632 & 4299342 & 4032925 \\
\hline probability & 0.000000 & 0.000000 & 0.000000 & 0.000000 & 0.108701 & 0.000000 & 0.000169 & 0.000000 & 0.000000 \\
\hline $\mathrm{um}$ & $\begin{array}{c}- \\
2,261,756 \\
\end{array}$ & 6200245 & 1383034 & 2784305 & $2.22 \mathrm{E}-26$ & 1207529 & 8042438 & 2397913 & $\begin{array}{l}3.44568 \\
\text { million. }\end{array}$ \\
\hline Sum Sq. Dev. & 6102261 & 6304959 & 21952.28 & 4014684 & $1,43 \mathrm{E}-51$ & 2076694 & 8662294 & 3373431 & $\begin{array}{c}5,87 \mathrm{E}+ \\
08 \\
\end{array}$ \\
\hline Observations & 280 & 280 & 280 & 280 & 280 & 280 & 280 & 280 & 280 \\
\hline
\end{tabular}

Source: Data processed in 2018

Based on the data from the table above, the mean value of the ERC in Table 1 shows -0.008 with a standard deviation of earnings information published 0,147 . It means responded negatively by the market. Trading volume (VPS) has a mean value of 0.2214 with a standard deviation of 0.475 indicates a high enough volume of data variation stock trading $22.14 \%$. 


\section{Hypothesis Testing Results}

Panel data regression test results for the first model are listed in Table 2

Table 2 Results Regression Model Research Panel 1

\begin{tabular}{|c|c|c|c|c|c|}
\hline & Prediction & B & Std.Error & $\mathrm{t}$ & Sign \\
\hline Constant & & -0.1229 & & & 0.0000 \\
\hline Growth & + & -0.0082 & 0.0000 & 139.3019 & 0.0000 \\
\hline Persistence & + & 0.0729 & 0.0029 & 25.1164 & 0.0000 \\
\hline Systematic Risk & - & 0.0000 & 0.0000 & 380.5452 & 0.0000 \\
\hline Capital Structure & - & -0.0020 & 0.0011 & -1.7154 & 0.0863 \\
\hline Size & + & 0.0026 & 0.0001 & 14.5933 & 0.0000 \\
\hline R-squared & & 0.9271 & \multirow{7}{*}{$* * *$} & & \\
\hline Adjusted R-Squared & & 0.9271 & & & \\
\hline F-Statistic & & 39892.4400 & & & \\
\hline Prob (F-Statistic) & & 0.0000 & & & \\
\hline Durbin-Watson Stats & & 2.1486 & & & \\
\hline Observations & & 280 & & & \\
\hline$*, * *, * * *=$ Significan & $\%, 5 \%$ & & & & \\
\hline
\end{tabular}

The results of one panel of data processing for the first course of a study model of the ERC as the dependent variable was said to fit with the results demonstrate the value of the F statistic 39892.44with a statistical probability of $0.0000(\alpha<5 \%)$. The R squared value of the first research model is equal to 0.9271 . This means that a variable persistence of earnings, systematic risk, and the company's growth affects the ERC by $92.71 \%$. The test results proved the research model panel 1 receives $\mathrm{H}_{1}$ with different influences that is where the company's growth negatively affect the ERC. Results H1 supports research Jang (2007) and Dira \& Astika (2014), Other than that, model test results also proved the first panel receiving $\mathrm{H}_{2}$ where systematic risk has a positive influence on the ERC. These results do not support research Easton and Zmijewski (1989); Collins and Kothari (1989); and Rofika (2015), namely that the Vendor has a high level of risk, low-profit information will be responded by the investor, which causes the lower ERC. However, the results support the research Palupi (2006) that the systematic risk in the shares of positive influence to the ERC. Furthermore, the results prove that the third hypothesis H3 is accepted that the ERC positively influenced significantly by the persistence of earnings.

Testing of the control variables comprising the capital structure and size of the company ERC give different results. Capital structure negatively affects the quality of earnings, where the research results together with the prediction of where the capital structure negatively affect earnings quality as measured by the ERC. Capital structure negatively affects the quality of earnings means that companies use leverage as the company's capital structure so small its value ERC. While the variable firm size positively affects the ERC with significant value $0,000<5 \%$. These results are consistent with the predictions in which the larger the company the more information is published, resulting in a high value of the ERC.

The results of the panel data processing for both research models with stock trading volume as the dependent variable is also said to be fit $289.2128 \mathrm{~F}$ value of 0.000 at a significance level $(\alpha<5 \%)$. R-square value amounted to 0.099 -second research model, which means that the variable ERC, the company's growth, systematic risk, JCI, and the USD exchange rate affects the trading volume amounted to $9.9 \%$. The results of the research model testing pool 2 prove that the $\mathrm{H} 4$ is accepted where ERC negatively affect the volume of stock trading. The results of the research model testing pool 2 evidenced receive H5, which means the company's growth directly affects the volume of stock trading. 
Table 3. Regression Results Panel 3 Research Model 2

\begin{tabular}{|c|c|c|c|c|c|}
\hline & Prediction & $\mathrm{B}$ & Std.Error & $\mathrm{t}$ & Sign \\
\hline Constant & & 1.1030 & & & \\
\hline ERC & + & -0.2762 & 0.0995 & -2.7757 & 0.0055 \\
\hline Growth & & -0.0093 & 0.0011 & -7.8881 & 0.0000 \\
\hline Persistence & & 0.9098 & 0.2331 & 3.9019 & 0.0001 \\
\hline Systematic Risk & & 0.0000 & 0.0000 & 0.8558 & 0.3921 \\
\hline CSPI & + & -1.2068 & 0.3111 & -3.8787 & 0.0001 \\
\hline USD & - & -0.0001 & 0.0000 & 11.7464 & 0.0000 \\
\hline R-squared & & 0.0996 & \multirow{7}{*}{$* * *$} & & \\
\hline Adjusted R-Squared & & 0.0993 & & & \\
\hline F-Statistic & & 289.2128 & & & \\
\hline Prob (F-Statistic) & & 0.0000 & & & \\
\hline Durbin-Watson Stats & & 1.5401 & & & \\
\hline Observations & & 280 & & & \\
\hline \multicolumn{3}{|c|}{$*, * *, * * *=$ Significance $1 \%, 5 \%, 10 \%$} & & & \\
\hline
\end{tabular}

The test results prove outcome research model 2 is refused $\mathrm{H} 7$ where systematic risk has no effect on stock trading volume, with significant value $0.3921>5 \%$. Results of testing the next hypothesis are H6 which proves that persistence of earnings directly affects the volume of stock trading, so it concluded H6 received significant value $0.0001<5 \%$.

\section{Variable Control}

Testing of the control variables of the stock trading volume provide results that JCI negatively affect the volume of stock trading at 0.0001 significance value $(<5 \%)$. This is consistent with the predictions where the low value of the stock index, investors gain high capital gains so that the public interest to buy shares will increase that directly affect the rise and fall of stock trading volume. And a variable rate of USD positive effect on the trading volume of 0,000 shares with a significance value of $<5 \%$. These results are consistent with the predictions due to the weakening of the rupiah exchange rate against the USD impact on the greater demand for shares by the market thereby increasing the volume of stock trading on the exchange.

\section{Testing Indirect and Direct}

Direct and indirect testing the company's growth, systemic risk, and the persistence of earnings to the volume of stock trading is evidenced by the results of the panel regression below

Table 4 Direct and Indirect Effect of Panel Data Regression

\begin{tabular}{|l|r|r|}
\hline \multicolumn{1}{|c|}{ Variables } & \multicolumn{1}{c|}{ Directly } & Indirect \\
\hline Growth companies $\rightarrow$ Volume of Stock Trading & -0.009391 & -0.008202 \\
\hline$\rightarrow$ Systematic Risk of Stock Trading Volume & $1,40 \mathrm{E}+25$ & No effect \\
\hline Persistence of Stock Trading Volume Profit $\rightarrow$ & 0.909873 & 0.072911 \\
\hline
\end{tabular}

Based on the findings of the above data can be interpreted as follows.

1. The company's growth has indirect influence value (-0.008) on the stock trading volume greater than the direct effect (-0.009). Thus, concluded that the ERC is a variable mediating between the company's growths to the volume of stock trading. 
2. Systematic risk only has a direct impact on the volume of stock trading $1,40 \mathrm{E}+25$, concluded that the ERC is not a mediating variable among the systematic risk of the stock trading volume. Earnings persistence has direct influence value (0.9098) against the stock trading volume greater than the indirect effect (0.0729). Thus, concluded that the ERC is a mediating variable between earnings persistence to the volume of stock trading.

\section{Discussion}

The test results prove that a hypothetical one company growth negatively affect earnings response coefficient. The results of different studies with the hypothesis being that a company's profit growth due to unexpected earnings of the current period. Market participants will respond negatively because it assumes that the unexpected earnings set by the management will impress that the company experienced growth (Dira \& Astika, 2014; Jang, 2007). Different results as evidenced by the second hypothesis, namely the systematic risk of the company positive effect on earnings response coefficient. Research compelling reasons why the results differ with the hypothesis proposed as potential investors in the country of Indonesia, on average invest for the short-term goals instead of the long-term so that less attention to the beta as a market risk at the time of the earnings information is announced. The results of these studies support the Palupi (2006) study that the systematic risk in the shares of positive influence to the ERC.

3 Hypothesis testing results have proved that the persistence of earnings affects earnings quality, as measured earnings response coefficient, positively. The results of the study support the research Kormendi and Lipe (1987), Easton and Zmijweski (1989), Mulyani et al. (2007). The reason is the company that has persistent earnings each period will provide security for market participants on the return that would be obtained in the future so that the value of the ERC is high. Testing $\mathrm{H}_{4}$ is that the negative effect on the volume of stock trading information published reason is that nature is not necessarily good news is trusted by market participants because they could assume the management company to intervene on the quality of the resulting company's profit (Otok et al., 2014). 5 hypothesis testing to prove that the company's growth directly affects the volume of stock trading. Results $\mathrm{H}_{5}$ and Halim and Hidayat (2000) support research that proves that the company's growth directly affects the stock trading volume (2000). The reason is that the company has a chance of growth opportunities in the future is a form of good news received so that market participants respond with increased market shares in the stock purchase amount (Halim \& Hidayat, 2000).

The next test is $\mathrm{H}_{7}$, where the result is a systematic risk has no effect on stock trading volume. The reason the situation occurs because the investment risks are perceived investors tend to be relatively stable and does not create fear within the investor, the situation continues to occur throughout the observation period, resulting in general stakeholders are trying to find other variables that are considered more affects the volume of stock trading company shares, such as the existence of the position inflation, exchange rates and interest rates that cannot be managed or predictable (Nasir \& Mirza, 2011). Results of testing the next hypothesis are $\mathrm{H} 6$ which proves that persistence of earnings directly affects the volume of stock trading. Earnings persistence means that the earnings capability as a parameter earnings in future periods (in earnings) generated the company repeatedly (repetitive) in the long term (sustainable) (Penman, 2001). Recurring profit generated is referred to as earnings quality (Penman, 2001), and earnings quality information is good news resulting in increased trading volume (buy shares) (Suryawijaya \& Setiawan, 1998).

\section{Conclusion}

The company's growth negatively affects the ERC. The reason is that a company's profit growth due to unexpected earnings of the current period. Market participants will respond negatively because it assumes that the unexpected earnings set by the management impressed that the company experienced growth. Systematic risk has a positive influence on the ERC. That is because investors in Indonesia, on average invest for the short-term goals instead of the long-term so that less attention to the beta as a market risk at 
the time of the earnings information is announced. Earnings persistence positive effect on the ERC. The reason is the company that has persistent earnings each period will provide security for market participants on the return that would be obtained in the future so that the value of the ERC is high. ERC negatively affect the volume of stock trading. The reason is that the nature of the information published is not necessarily good news is trusted by market participants because they could assume the management company to intervene on the quality of the resulting company's earnings. The company's growth directly affects the volume of stock trading.

The reason is that the company has a chance of growth opportunities in the future is a form of good news received by market participants that the market responds with an increase in the purchase of shares on the exchange. Systematic risk no direct impact on the volume of stock trading. The reason the situation occurs due to the perceived investment risk investors tend to be relatively stable and does not create fear within the investor, situation continued throughout the observation period, resulting in general stakeholders are trying to find other variables that are considered more affects the volume of stock trading company shares, such as the existence of the position of inflation, exchange rates and interest rates that cannot be managed or predictable. The persistence of earnings directly affects the volume of stock trading. Earnings persistence means that the earnings capability as a parameter earnings in future periods (in earnings) generated the company repeatedly (repetitive) in the long term (sustainable).

Recurring profit generated is referred to as earnings quality and earnings quality information is good news that resulted in an increased volume of stock trading (buying stocks). Consequently, generally stakeholders trying to look for other variables that are considered more affects the volume of stock trading company shares, such as the existence of the position of inflation, exchange rates and interest rates that cannot be managed or predictable. The persistence of earnings directly affects the volume of stock trading. Earnings persistence means that the earnings capability as a parameter earnings in future periods (in earnings) generated the company repeatedly (repetitive) in the long term (sustainable).

Recurring profit generated is referred to as earnings quality and earnings quality information is good news that resulted in an increased volume of stock trading (buying stocks). Consequently, generally stakeholders trying to look for other variables that are considered more affects the volume of stock trading company shares, such as the existence of the position of inflation, exchange rates and interest rates that cannot be managed or predictable. The persistence of earnings directly affects the volume of stock trading. Earnings persistence means that the earnings capability as a parameter earnings in future periods (in earnings) generated the company repeatedly (repetitive) in the long term (sustainable). Recurring profit generated is referred to as earnings quality and earnings quality information is good news that resulted in an increased volume of stock trading (buying stocks).

Limitations of the study are the research results cannot be generalized to all companies, especially small companies, because of research using a sample of large visible Vendor of listed in Indonesia Stock Exchange. Implications for further research adds a control variable for the second model, the right issue. Terms of issuance of the rights issue are usually no provisions for the new shares as investors slots must be at least 10 old shares for new shares purchased 7 lots, where 1 lot of 100 shares. This led to the company trying to collect as much fatherly lot acquire the rights issue, the impact is an increase in the number of shares traded on the exchange.

\section{Acknowledgement}

I thank God for the completion of this research in fulfilling the duties of a financial accounting doctoral seminar. I hope this research can be useful for potential investors in terms of investing considerations. 


\section{References}

Afni, S. M., Ratnawati, V., \& Basri, Y. M. (2015). Pengaruh Persistensi Laba, Alokasi Pajak Antar Periode, Ukuran Perusahaan, Pertumbuhan Laba Dan Profitabilitas Terhadap Kualitas Laba (Studi Empiris Pada Perusahaan Manufaktur Yang Terdaftar Di BEI 2010-2012). Jurnal Online Mahasiswa (JOM) Bidang Ilmu Ekonomi, 1(2), 1-21.

Ahmadillah, H. (2013). Pengaruh Leverage, Risiko Sistematik Dan Kualitas Auditor Terhadap Relevansi Nilai Laba Akuntansi (Studi Empiris pada Perusahaan Manufaktur yang Terdaftar di BEI). Jurnal Akuntansi Universitas Negeri Padang, 1(3).

Ali, A., \& Zarowin, P. (1992). The Role of Earnings Levels in Annual Earnings-Returns Studies. Journal of Accounting Research, 30(2), 286-296.

Ambarwati, Sri. (2008). Earnings Responses Coefficient. Akuntabilitas, 7 (2): 128-134.

Billings, B. (1999). Revisiting the Relation between the Default Risk of Debt and the Earnings Response Coefficient. The Accounting Review, 74(4), 509-522.

Bodie, Z., Kane, A., \& Marcus, AJ. (2011). Investments and portofolio Management. Global Edition. New York : The McGraw-Hill Companies, Inc.

Brigham, E. F., \& Houston, J. F. (2010). Dasar-dasar Manajemen Keuangan Buku 1, Edisi 11. Jakarta: Salemba Empat.

Chandrarin, G. (2003). The Impact of Accounting Methods For Transaction Gains (Losses) on The Earnings Response Coefficient: The Indonesian Case. Jurnal Riset Akuntansi Indonesia, 6 (3), 217-231

Collins, D.W.\& S.P. Kothari. (1989). An Analysis of the Intemporal and Cross-Sectional Determinants of Earnings Response Coefficient. Journal of Accounting and Economics, 11(2-3), 143-181. http://dx.doi.org/10.1016/0165-4101(89)90004-9

Dechow, P., Ge, W., \& Schrand, C. (2010). Understanding earnings quality: A review of the proxies, their determinants and their consequences. Journal of accounting and economics, 50(2-3), 344-401.

Dhaliwal, D. S. \& N. L. Farger. (1991). The Association Between Unexpected Earnings And Abnormal Security Returns In The Presence of Financial Leverage. Contemporary Accounting Research. 8: 2041. http://dx.doi.org /10.1111/j.1911-3846.1991.tb00832.x

Dhaliwal, D., Li, O., Tsang, A., \& Yang, Y. (2011). Voluntary Nonfinancial Disclosure and the Cost of Equity Capital: The Initiation of Corporate Social Responsibility Reporting. The Accounting Review, 86(1), 59-100. http://remote-lib.ui.ac.id:2059/stable/29780225

Dira, Kadek Prawisanti \& Ida Bagus Putra Astika. (2014). Pengaruh Stuktur Modal, Likuiditas, Pertumbuhan Laba, dan Ukuran Perusahaan Pada Kualitas Laba. E-Jurnal Akuntansi Universitas Udayana. 7.1: 64-78. ISSN.2302-8556

Easton, P. D., \& Harris, T. S. (1991). Earnings as an explanatory variable for returns. Journal of Accounting Research, 29(1), 19-36. https://doi.org/10.1016/0165-4101(89)90003-7

Francis, J., LaFond, R., Per M. Olsson, \& Schipper, K. (2004). Costs of Equity and Earnings Attributes. The Accounting Review, 79(4), 967-1010. Retrieved from Retrieved from http://remotelib.ui.ac.id:2059/stable/4093083

Ghozali, Imam. (2016). Aplikasi Analisis Multivariate dengan Program IBM SPSS 23, Edisi 8. Semarang: Badan Penerbit Universitas Diponegoro.ISBN: 979.704.015.1

Gujarati, Damodar N. \& Dawn C. Porter. (2009). Basic Econometrics. McGraw Hill. International Edition.

Hadya, Rizka. (2013). Pengaruh Harga dan Risiko Saham Terhadap Likuiditas Saham Pada Perusahaan yang Terdaftar di BEI. Jurnal BKP, 1(2), 208-231.

Halim, Abdul dan Nasuhi Hidayat. (2000). Studi Empiris Tentang Pengaruh Volume Perdagangan dan Return Terhadap Bid-Ask Spread Saham Industri Rokok di BEJ dengan Model Korelasi Kesalahan. Jurnal Riset Akuntansi Indonesia, 3, 69-85.

Harahap, Sofyan Syafri. (2004). Akuntansi Aktiva Tetap, Edisi Ketiga. Jakarta: PT. Raja Grafindo.

Hartono, Jogiyanto. (2015). Teori Portofolio dan Analisis Investasi. Yogyakarta: BPFE.

Ilvia, Regina, Rika Desiyanti, dan Nailal Husna.

Jang, L., Sugiarto, B., \& Siagian, D. (2007). Faktor-Faktor Yang Mempengaruhi Kualitas Laba Pada Perusahaan Manufaktur di BEJ. Jurnal Riset Akuntansi Indonesia, 6(2), 142-149. 
Jensen, M. \& Meckling. W. (1976). Theory of the Firm: Managerial Behavior, Agency, and Ownership Structure. Journal of Financial Economic, 3(4), 305-360. https://doi.org/10.1016/0304405X(76)90026-X

Kormendi, R. \& Lipe, R. (1987). Earnings Innovations, Earnings Persistence And Stock Return. Journal of Bussiness, 60(31), 323-345. http://dx.doi.org/10.1086/296400

Mayangsari, S. (2004). Bukti Empiris Pengaruh Spesialisasi Industri Auditor Terhadap Earning Response Coefficient. Jurnal Riset Akuntansi Indonesia, 7(2), 154-178.

Mulyani, S., Asyik, N.F., \& Andayani. (2007). Faktor-Faktor yang mempengaruhi Earnings Response Coefficient pada Perusahaan yang Terdaftar di Bursa Efek Jakarta. Jurnal Akuntansi dan Auditing Indonesia, 11(1), 35-45.

Murwaningsari, E. (2008). Pengujian Simultan: Beberapa Faktor yang Mempengaruhi Earning Response Coefficient (ERC). stiepena.ac.id/wp-content/uploads/2012/02/paper8.doc.

Otok, B. W., Guritno, S., \& Suban (2006). Faktor-faktor yang Mempengaruhi Volume Perdagangan Saham Menggunakan Multivariate Adaptive Regression Splines. Jurnal Widya Manajemen dan Akuntansi, 6(3), 303-316.

Palupi, M. (2006). Analisis Faktor Faktor Yang Mempengaruhi Koefisien Respon Laba Bukti Empiris pada Bursa Efek Jakarta. Jurnal EKUBANK, Vol 3. http://repository.univpancasila.ac.id/dmdocuments. Diakses 20 Mei 2017.

Rachmawati, S. (2008). Pengaruh Faktor Internal dan Eksternal Perusahaan terhadap Audit delay dan Timeliness. Jurnal Akuntansi dan Keuangan, 10(1), 1-10.

Rofika. (2015). Faktor-faktor yang Mempengaruhi ERC Perusahaan Manufaktur yang terdaftar di Bursa Efek Indonesia 2012. Jurnal Akuntansi. 3(2, 174-183. ISSN: 2337-4314.

Rosdini, D. (2010). Pengaruh Investment Opportunity Set dan Corporate Governance terhadap Kualitas Laba. Jurnal Akuntansi dan Keuangan. 5(2).

Sandi, K. U. (2013). Faktor-Faktor yang Mempengaruhi Earnings Response Coefficient. Accounting Analysis Journal. ISSN: 2252-6765.

Sartono, R. A. (2014). Manajemen Keuangan: Teori dan Aplikasi Edisi 4. Yogyakarta: BPFE.

Scott, W. R. (2015). Financial Accounting Theory, $7^{\text {th }}$ edition. Toronto: Pearson.

Sharpe, W. F. (1963). A Simplified Model for Portfolio Analysis. Management Science 9 (January 1963): 277-293.

Masri, S., \& Effendi, S. (2009). Metode Penelitian Survei, Jakarta: LP3ES

Solechan, A. (2006). Pengaruh Earning, Manajemen Laba, IOS, Beta, Size dan Rasio Hutang Terhadap Return Saham pada Perusahaan yang Go Public di BEI. Jurnal STMIK HIMSYA: 1-18.

Stice \& Skousen. (2009). Akuntansi Intermediate. Edisi Keenam Belas, Buku 1. Jakarta: Salemba Empat.

Subagyo, O. (2012). Faktor-faktor yang Mempengaruhi ERC. Jurnal Akuntansi, 12(1), 539-558.

Sugiyarto. (2012). Indonesia Masuk 5 Besar Emerging Market Dunia. http://www.tribunnews.com.

Sugiyono. (2016). Metode Penelitian Kuantitatif Kualitatif dan R\&D. Bandung: Alfabeta.

Sunariyah. (2000). Pengetahuan Pasar Modal. Yogyakarta: UUP-AMP YKPN

Suryawijaya, M.A. \& Setiawan, F.A. 1998. Reaksi Pasar Modal Indoneisa terhadap Peristiwa Politik

Dalam Negeri (Event Study pada Peristiwa 27 Juli 1996). Yogyakarta: Kelola Universitas Gadjah Mada.

Susanto, Y.K. (2012). Determinan Koefisien Respon Laba. Jurnal Akunansi \& Manajemen, 2(3). ISSN: 0853-1259.

Sutrisno, W. (2000). Pengaruh Share Split Terhadap Likuiditas dan Return Saham di Bursa Efek Jakarta. Jurnal Manajemen dan Kewirausahaan, 2(2): 1-13

Tandelilin, E. (2010). Portofolio dan Investasi Teori dan Aplikasi. Edisi pertama. Yogyakarta: Kanisius.

Tiolemba, N. \& Erni E. (2008). Analisis Faktor-faktor yang Mempengaruhi Koefisien Respon Laba pada Perusahaan Manufaktur yang Terdaftar di BEJ. Jurnal Riset Akuntansi dan Keuangan Vol. 4.

Volume Perdagangan Saham Terhadap Return Saham Pada Perusahaan Perbakan Yang Terdaftar di Bursa Efek Indonesia, Jurnal Ekonomi, 9(4). ISSN: 0853-7953.

Wijayanti. (2006). Analisis Pengaruh Perbedaan Antara Laba Akuntansi dan Laba Fiskal Terhadap Persistensi Laba, Akrual, dan Kas. Makalah Simposium Nasional Akuntansi IX. 